\title{
A TITLE PAGE OF MICHAEL PRAETORIUS
}

\author{
PETER HOLMAN \\ University of Leeds
}

Izvleček: Vsem dobro znana naslovna grafika, ki jo je Michael Praetorius uporabil v več svojih tiskanih delih, lahko služi kot izhodišče za razpravljanje o načinu izvajanja glasbe za velike sestave $v$ Nemčiji v zgodnjem 17. stoletju. Razprava se osredotoča na upodabljanje skladateljev z zvitkom papirja v rokah, kar je primer prakse nakazovanja glasbene dobe $v$ 17. stoletju, in ugotavlja, kako se ta praksa razlikuje od današnjega dirigiranja.

Ključne besede: Michael Praetorius, Giovanni Gabrieli, Johann Hermann Schein, naslovnica, nakazovanje dobe

\begin{abstract}
The well-known title page used by Michael Praetorius for several of his publications provides a starting-point for a discussion of the way large-scale music was directed in early seventeenth-century Germany. The practice of depicting composers with rolls of paper is discussed, as is the nature of seventeenth-century time-beating and how it differed from modern conducting.
\end{abstract}

Keywords: Michael Praetorius, Giovanni Gabrieli, Johann Hermann Schein, title page, time-beater

A familiar, arresting image (Figure 1), the design Michael Praetorius used for a number of his publications, provides us with a convenient starting point for a discussion of musical direction in the early seventeenth century, particularly in large-scale Italian and German music. ${ }^{1}$ As well as serving as a decorative border for the typeset titles of the respective publications, starting in 1605 with the first part of Musae Sionae and ending with Theatrum instrumentorum in $1620,{ }^{2}$ it is also an ingenious evocation of polychoral music being performed in what appears to be a princely chapel. It was perhaps intended to evoke the long-lost chapel in the castle at Wolfenbüttel, where Praetorius worked on and off from the 1590s until his death in 1621. As we shall see, the image can tell us a good deal about musical direction at the time, despite the fact that Praetorius did not complement it with a detailed discussion of the topic in his published writings. It is possible that he intended to make good this deficiency in the volumes of Syntagma musicum that

1 A more extended discussion of this topic will appear in my forthcoming book Before the Baton.

2 Digital copies are conveniently collected on the IMSLP website: https://imslp.org/wiki/ Category:Praetorius,_Michael. 


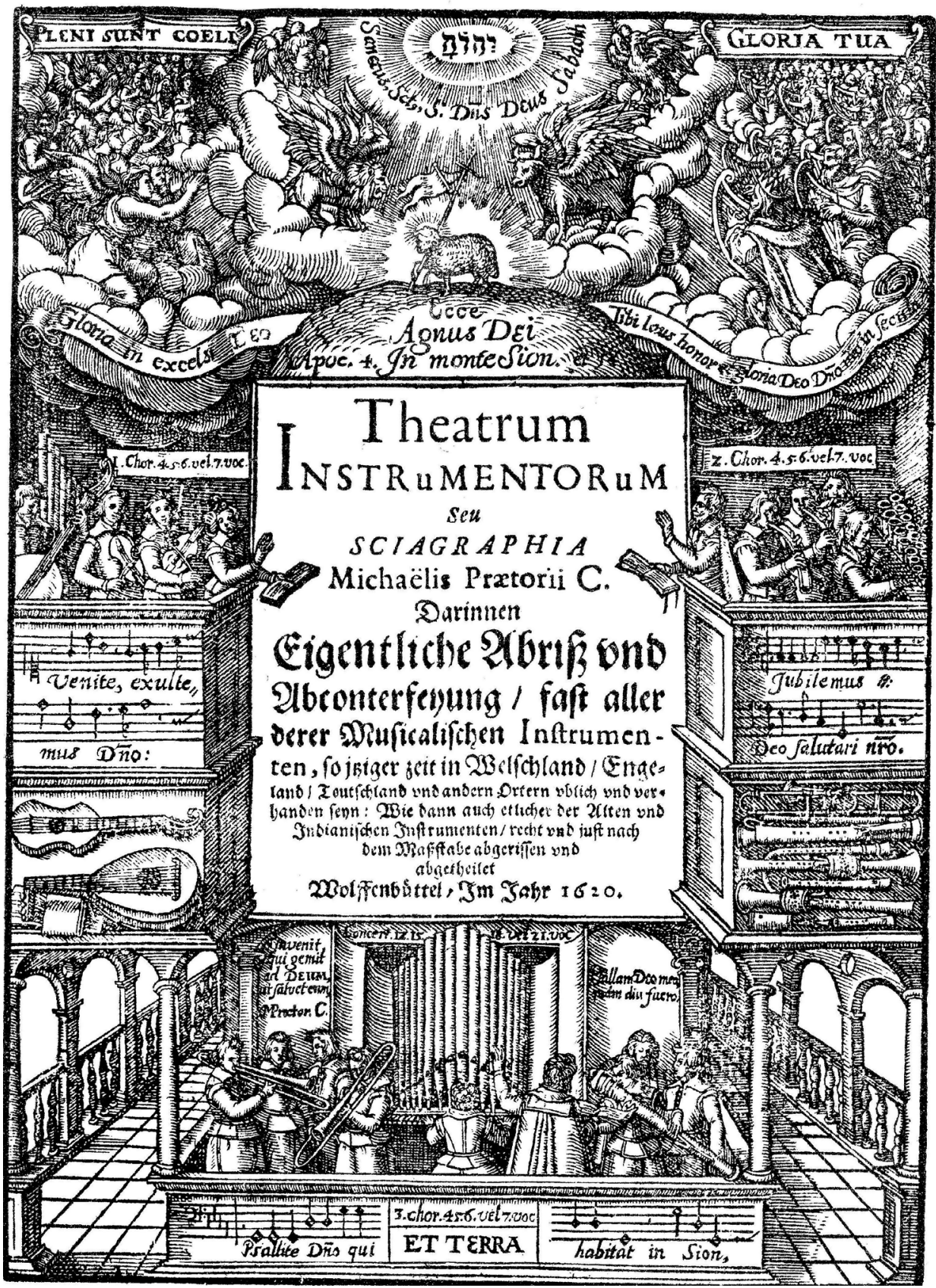

Figure 1

The title page of Michael Praetorius, Theatrum instrumentorum, Wolfenbüttel, 1620. (Public domain.) 
remained unpublished at his untimely death in 1621. According to the brief description of them he inserted near the end of vol. 3, vol. 12 was to be an "Instruction on how diverse concertos can be arranged for few and many choirs in a variety of styles, formulated for musical directors [Capellmeistern] and singers for further consideration". ${ }^{3}$

By 1600 professional musicians in Germany and most other areas of Europe had been performing polyphonic music for several centuries, and therefore did not need anyone to beat time in small groups. Thus, when we see someone doing so in a seventeenth-century picture it probably signifies a group made up partly or wholly of amateurs. A case in point is the vignette on the title page of Johann Martin Rubert's Musikalischen Arien erster Theil, published in Stralsund in 1647 (Figure 2). It presumably illustrates a performance of music from the volume, with three singers, two violins, a bass violin or viol, two lutes and a spinet. The motto "Musica noster amor" suggests that it depicts a music club or collegium musicum in the Hanseatic town of Stralsund, where Rubert was organist of the Nikolaikirche. ${ }^{4} \mathrm{He}$ is presumably the person playing the spinet and is the real director of the ensemble; the singing time-beater is probably just a club member.

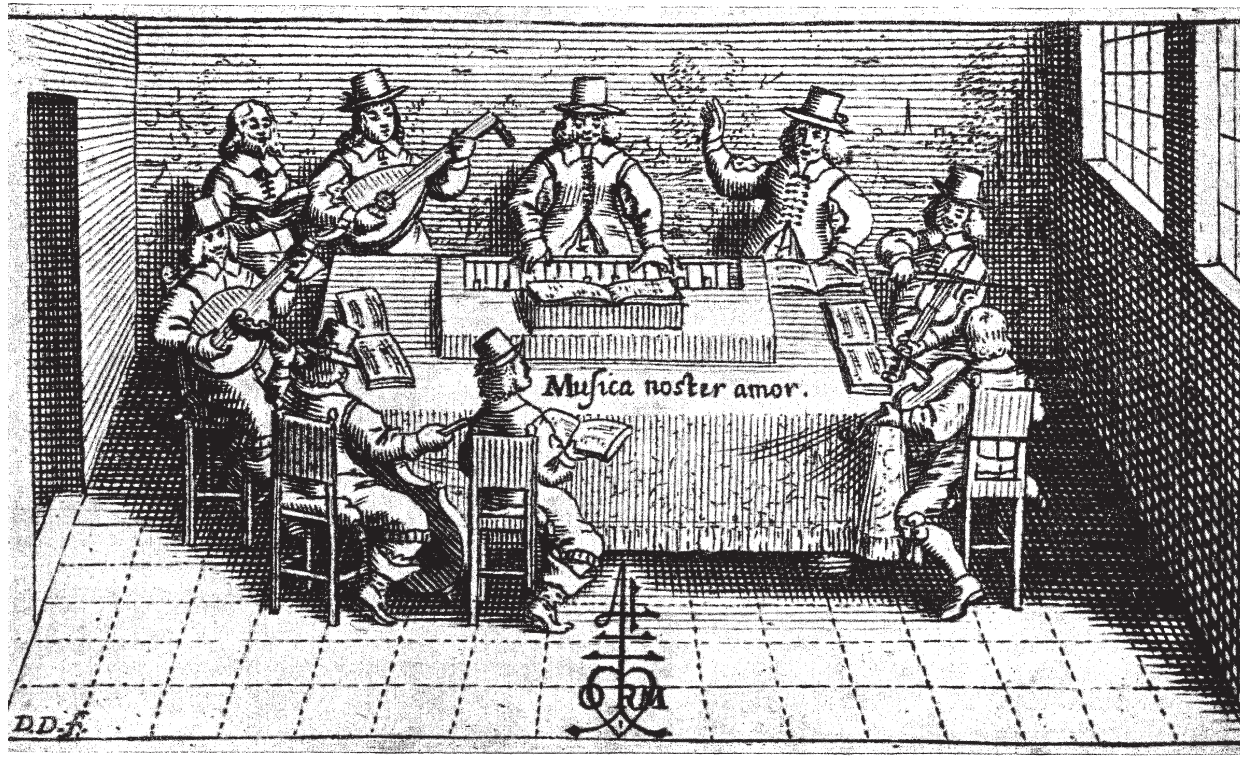

Figure 2

Block illustrating the title page of Johann Martin Rubert, Musikalischen Arien erster Theil, Stralsund, 1647. (Public domain.)

As this picture suggests, time-beating was often done by singers simply because they did not have to hold or play an instrument and therefore usually had a hand free. Among

3 Praetorius, Syntagma musicum III, 209-210.

4 For Rubert, see Kirwan and Hoffmann-Erbrecht, "Johann Martin Rubert". 
instrumentalists, lutenists had the advantage that the necks of their instruments could easily be waved and were highly visible. Mersenne wrote in the 1630 s that "those who currently lead concerts" in Paris "mark the beat" ("marquent la mesure") for the singers with "the movement of the neck of the lutes of theorboes on which they play", ${ }^{5}$ while the unknown author of the Burwell Lute Tutor, an English manuscript of the 1660s, wrote that "in a Consort one beates it [the time] with the motion of the necke of the Theorbo, and every one must have the eye upon it and following in playing his motion and keep the same time with the other players". ${ }^{6}$ A violin bow is another obvious time-beating implement, much used for this purpose from the early eighteenth century onwards, but, rather surprisingly, there seems to be no evidence for violinists directing large ensembles until the late seventeenth century; an early example is a picture of Corelli directing an outdoor performance of a serenata in Rome in 1687.7 He stands on a platform with the second concertino violinist, where they can be seen by all the other performers: five singers, two lutenists, two harpsichordists and a string orchestra of fifty-seven.

Returning to Praetorius's title page, in the earthly part of the image - as opposed to the vision of Heaven at the top - we see three groups of musicians, labelled respectively Choir 1 (top left), Choir 2 (top right) and Choir 3 (bottom). Choir 3 consists of nine musicians. There seem to be two trombonists and two singers on the left; two more singers and a large woodwind instrument, possibly a sordun, on the right; ${ }^{8}$ and a large organ in the centre, with a figure beating time standing behind the organist. Choirs 1 and 2 are in two facing galleries at first-floor level. On the left there is a time-beating singer with instrumentalists playing what appear to be a violin, a viola and a large four-string bass violin; at the back of this gallery we can see the pipes of a second, rather smaller organ. On the right there is a choir seemingly consisting of another singer with three cornett players, accompanied by a fifth musician playing a regal with conical resonators.

The first thing to notice is that this three-choir ensemble is directed by three timebeaters, one in each choir. We will see that it was common practice in polychoral music for the principal time-beater to stand next to the main organ, and for his beat to be relayed by subsidiary time-beaters stationed in each choir, so we can presume that Praetorius's Kapellmeister is at the bottom of the image, with Choir 3. The three time-beaters hold part-books in one hand and beat time with the other. I call them time-beaters because their function was just to use simple vertical hand movements to maintain good ensemble, not to do all the other things required from modern conductors - who of course need to use both hands for this reason.

It is not clear whether the Kapellmeister is meant to be singing as well as beating

5 “[...] par le mouuement du manche des Luths ou des Tuorbes, dont ils ioüe[n]t." Mersenne, Harmonie universelle, 324v-325. I am grateful to Thérèse de Goede for drawing my attention to this passage and for providing me with a translation. A full transcription and discussion will appear in Holman, Before the Baton.

6 Spencer, "Chitarrone, Theorbo and Archlute", 413.

7 Reproduced in Spitzer and Zaslaw, Birth of the Orchestra, 112, fig. 4.1. There are also digital images, such as at https://artsandculture.google.com.

8 I am grateful to Wouter Verschuren for suggesting to me that it was intended to be a sordun rather than a dulcian, my initial identification. 


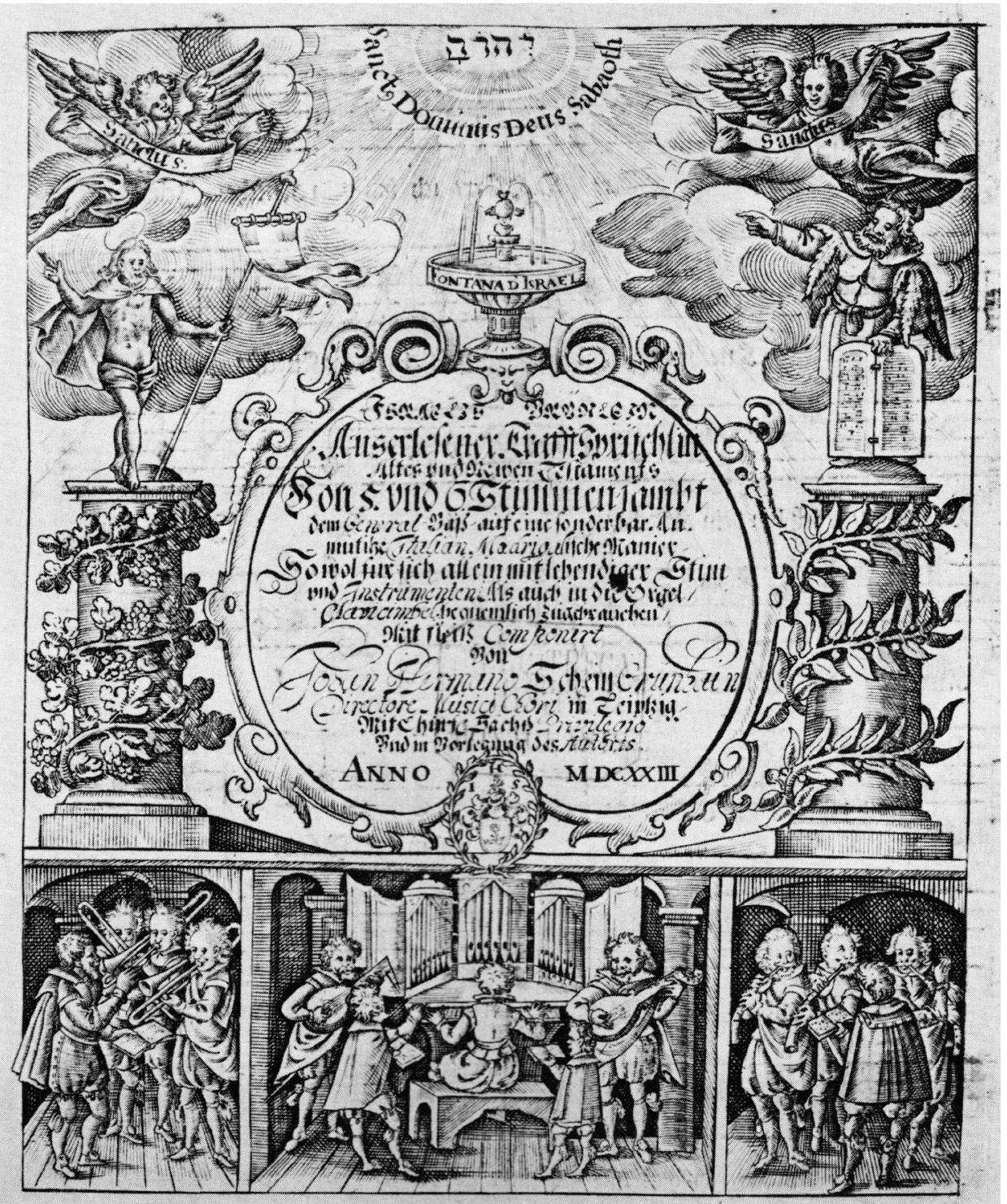

Figure 3

The title page of Johann Hermann Schein, Fontana d'Israel / Israelis Brünlein, Leipzig, 1623. (Public domain.)

time, but the other two time-beaters are probably doing both. Depicting singers holding music was an obvious way for artists and engravers to signal their status as musicians. By contrast, instrumentalists are often depicted without music, in part presumably because their instruments sufficiently identified them as musicians, but also because professional 
instrumental ensembles traditionally performed in public from memory, as with the six-man wind group portrayed in one of Denis van Alsoot's paintings of the Triumph of the Archduchess Isabella, a processional pageant performed in the streets of Brussels on 31 May 1615, ${ }^{9}$ or the engraving of the funeral of Charles III of Lorraine at Nancy on 19 July $1608,{ }^{10}$ in which the singers have part-books but the instrumentalists do not. A state funeral of this sort would have required specially composed (or at least specially revived) polyphonic music, so it is hard to believe that the instrumentalists had really memorized their parts at short notice.

Praetorius's image can also be usefully compared with another title page of the period, for Johann Hermann Schein's Fontana d'Israel or Israelis Brünlein, published in Leipzig in 1623 (Figure 3). In the panel at the bottom we are clearly looking at another three-choir group of voices and instruments, so it is hard to understand why it was used to illustrate a set of Italianate motets, scored for a single choir of five- and six-part voices with continuo. Be that as it may, the central group in the panel consists of two people holding music: one an adult beating time (presumably the Kapellmeister), the other a boy accompanied by two lutes and organ. On the left is a choir apparently consisting of a time-beating singer with three trombones, and on the right a matching choir with a singing time-beater and three cornetts. The title page may therefore depict the performance of a nine- or ten-part motet: one or two solo voices with continuo (depending on whether we think the timebeater is also singing) are contrasted with two four-part choirs: one with three cornetts and a singer, the other with a singer and three trombones.

Matched high- and low-pitched choirs of this sort, with adult male singers taking the lowest part of a cornett choir and the highest part of a trombone choir, form virtually a standard combination in Giovanni Gabrieli and his German imitators, who include Praetorius, Schütz and Schein. In Gabrieli the third choir is often a capella, a four-part ensemble that could helpfully use up the remaining singers and instrumentalists in a church or court establishment. ${ }^{11}$ So, turning back to the Praetorius title page (Figure 1), we can see that Choir 3, at the bottom, is clearly meant to be the capella, comprising four singers, three instruments and organ.

It is well known, of course, that Praetorius was an apostle for the Gabrieli style in Germany. He never visited Italy, prevented from doing so, he claimed in Syntagma

9 Madrid, Museo del Prado, PO1348; reproduced, for instance, in Coelho and Polk, Instrumentalists and Renaissance Culture, fig. 6.26; there are also digital images, for example at https://commons. wikimedia.org/wiki/Category:Denis_van_Alsloot.

${ }^{10}$ Brentel and Merian, Decem insignae tabulae, pl. 7; see also Bowles, Musical Ensembles in Festival Books, 157, fig. 67, 67a.

${ }^{11}$ See the definitions of capella in Praetorius, Syntagma musicum III, 124-126. For Gabrieli's scorings, see Charteris, Giovanni Gabrieli. Gabrieli's use of high- and low-pitched choirs can be conveniently seen in the complete edition of Symphoniae sacrae [...] liber secundus (Venice, 1615), edited by Peter Rottländer and available on the Choral Public Domain Library site. See, for instance, the 8-part "Benedictus es, Dominus" (no. 11), the 10-part "Deus, Deus meus" (no. 13) or the 12-part Magnificat (no. 23), the last scored for high- and low-pitched choirs with a capella. 
musicum, "because of ill health, his duties, and many other misfortunes". ${ }^{2}$ However, in his writings and in his own music he demonstrates an encyclopaedic knowledge of Italian polychoral music in printed collections, and he is known to have worked in Kassel, where Gabrieli's pupil Heinrich Schütz wrote his early polychoral music. The court music collection at Kassel still includes some unpublished late Gabrieli works, including the spectacular three-choir "sonata con voce" Dulcis Jesu, patris imago. ${ }^{13}$ Praetorius also worked in Dresden for much of the time between 1613 and 1618, where he would again have encountered Schütz and the latter's own Italianate polychoral music.

Most of the little information Praetorius provided in Syntagma musicum on the subject of musical direction was not written by him but was summarized from the preface to Viadana's Salmi a quattro cori, published in Venice in $1612 ;{ }^{14}$ at that time Lodovico Grossi da Viadana was maestro di capella at Fano, in the Marche region of Italy south of Pesaro. To summarize, Viadana suggested that his Choir 1 should consist of five solo singers standing next to the main organ; Choir 2, the capella, should consist of at least sixteen singers but makes an excellent effect with twenty to thirty voices and instruments; Choirs 3 and 4 should be high- and low-pitched choirs respectively, with a flexible mixture of voices and instruments. The psalms can be performed just by Choirs 1 and 2, or by up to eight choirs by doubling Choirs 2, 3 and 4 .

Viadana's director - il maestro di capella - should stand with Choir 1, "always watching the organist's continuo part", "paying attention to the progress of the music" and indicating the various entries. Interestingly, this is at variance with Praetorius's title page, where the maestro holds his own music and stands with the capella. Viadana also asked that in the tutti sections the maestro should "turn to face all the choirs, raising both arms, a sign that everyone sings together". By looking at the continuo part over the organist's shoulder he was free to use both hands to beat time, which explains a puzzling feature of some later pictures. J. C. Weigel's Music-Director, published in about 1722, ${ }^{15}$ shows the time-beater grasping two rolls of paper, one in each hand, a feature also found in the famous frontispiece of J. G. Walther's Musicalisches Lexicon (Leipzig, 1732). ${ }^{16}$ Weigel's Music-Director reads from a score entitled "Motetto à 2. Chori" while Walther's time-beater - sometimes implausibly said to be J.S. Bach - is clearly directing several choirs of voices and instruments. Double-choir music was apparently thought to require the use of both hands, one for each group.

Viadana did not mention that subsidiary time-beaters could be used to relay the beat, but this practice is mentioned in the description by the French viol player André Maugars of music performed for the feast of St Dominic at Santa Maria sopra Minerva in Rome on 3 and 4 August 1639. There were ten choirs, two with the main organs in the choir

12 Praetorius, Syntagma musicum III, 9.

${ }^{13}$ The Kassel holdings of Gabrieli are conveniently listed and discussed in Charteris, "Newly Discovered Works by Giovanni Gabrieli”, 352-355.

${ }_{14}$ Viadana, Salmi a quattro cori, 2-3; Praetorius, Syntagma musicum III, 116.

${ }^{15}$ Weigel, Musicalisches Theatrum, vol. 1, pl. 24.

${ }^{16}$ Reproduced, for instance, in Kinsky, History of Music, 255; a digital copy of the book is at https:// imslp.org/wiki/Musicalisches_Lexicon_(Walther,_Johann_Gottfried). 
lofts either side of the altar and eight with portable organs on temporary platforms along each side of the nave. Maugars added: "The master composer beat time in the first choir, consisting of the best voices. With each of the others there was a man who did nothing but keep his eyes on this main beat, synchronizing his beat with it, so that all the choirs sang together without dragging". ${ }^{17}$ Relaying the beat in this way meant that it was not necessary for the maestro to be seen by all the subsidiary time-beaters - a useful technique in Baroque churches with multiple galleries facing in different directions.

Viadana and Maugars help us to understand the famous description by the English traveller Thomas Coryat of the patronal festival at the Scuola di San Rocco in Venice on 6 and 7 August 1608; the music was organized by Giovanni Gabrieli, its organist. ${ }^{18}$ Coryat wrote: "Sometimes there sung sixteene or twenty men together, hauing their master or moderator to keepe them in order; and when they sung, the instrumentall musitians played also"; his description taken with payments for the event shows that nearly fifty musicians took part. ${ }^{19}$ Coryat added: "at euery time that euery seuerall musicke played, the Organs, whereof there are seuen faire paire in that roome, standing al in a rowe together, plaied with them", suggesting that there were seven choirs arranged around the room, each accompanied by an organ. Gabrieli played one of them and presumably wrote some or all the music for the occasion, including, perhaps, his partly lost seven-choir thirty-threepart Magnificat. ${ }^{20}$ However, the "master or moderator" must have been Bortolo Morosini, maestro for the festival - an indication that seventeenth-century composers did not automatically beat time in their own music; in fact, seventeenth-century time-beaters could be relatively unimportant functionaries. Coryat did not say so, but each choir probably had a time-beater relaying the beat.

These two ideas - that composers or maestri were not necessarily the time-beaters and that subsidiary time-beaters were used to relay the beat in polychoral music - are reinforced by a document relating to music at San Marco in Venice in, most likely, 1607. ${ }^{21}$ It reveals that Giovanni Croce, the maestro, had employed Giovanni Bassano, the leader of the instrumentalists - capo dei concerti - to "show the beat as regulated by this maestro". ${ }^{22}$ Bassano was placed in Giovanni Gabrieli's organ loft (Gabrieli, the second organist, played a small instrument in the south gallery), ${ }^{23}$ while a singer, Fra Agostin, performed the same function in the north gallery. Brother Augustine had gone absent without leave, hence the need for the document.

17 "Le maistre Compositeur battoit la principale mesure dans le premier chœur, accompagné des plus belles voix. A chacun des autres il y auoit vn homme qui ne faisoit autre chose que ietter les yeux sur cette mesure primitiue, afin d'y conformer la sienne; de sorte que tous les chœurs chantoient d'vne mesme mesure, sans traisner." Maugars, Response faite à un curieux, 7-8; translation adapted from MacClintock, Readings in the History of Music in Performance, 118.

${ }^{18}$ Coryat, Coryat's Crudities, 251-253.

${ }^{19}$ For the event, see in particular Arnold, Giovanni Gabrieli, 200-210; Glixon, Honoring God and the City, 157-161, 285.

${ }^{20}$ Charteris, Giovanni Gabrieli, 224; Glixon, Honoring God and the City, 320, fn. 45.

${ }^{21}$ Bryant, "Cori Spezzati of St. Mark's", 181-182.

22 "[...] à dimostrar la batuda si come viene regolata da esso Maestro."

${ }^{23}$ Selfridge-Field, "Gabrieli and the Organ". 
Figure 4

Portrait of Michael Praetorius, first published in Musae Sionae, part 1, Wolfenbüttel, 1605. (Public domain.)

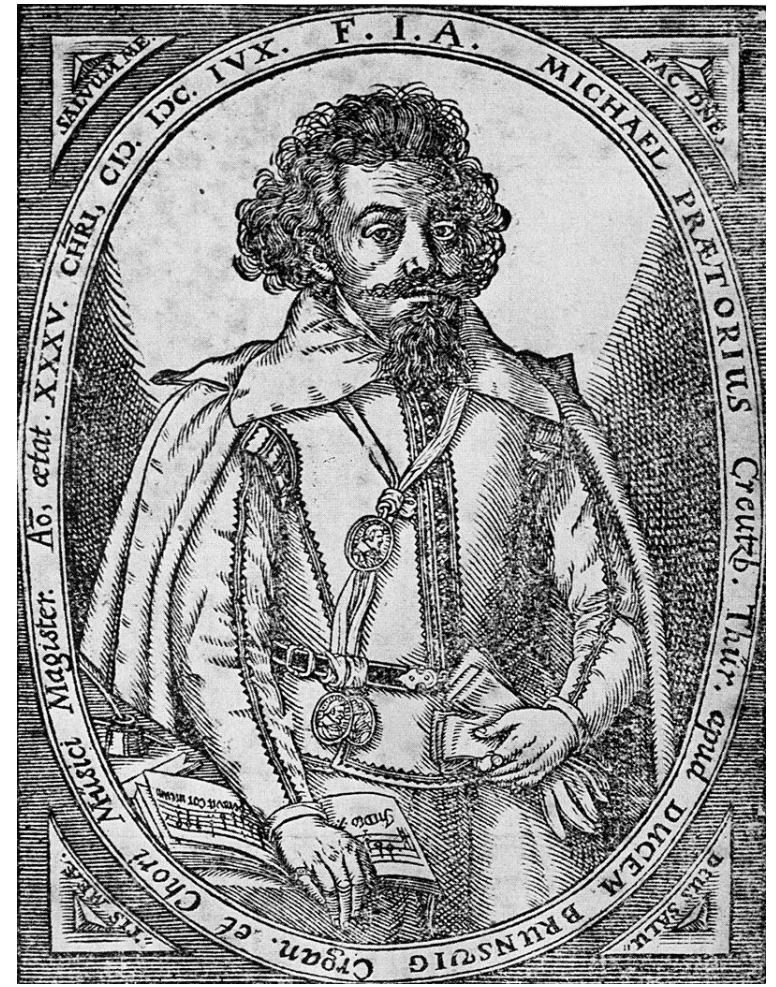

The pictorial evidence suggests that it was the norm until the early seventeenth century for time-beaters just to use their hands, although after that it became increasingly common for them to grasp an implement to amplify the beat, such as a thick baton of the sort used by military leaders as a symbol of their authority or, most commonly, a simple roll of paper. This change went hand-in-hand with the fashion for full-time time-beaters not participating in the ensemble as singers or instrumentalists. The time-beaters in Praetorius's title page just use their hands, and it may be that his practice was conservative compared with that of his younger contemporaries. He is not depicted with a roll of paper in his famous portrait, first published in 1605 in the first part of Musae Sionae (Figure 4), despite the fact that he is described in the inscription around the border as organist and "Chori Musici Magister" of his employer, Heinrich Julius of Brunswick-Wolfenbüttel. ${ }^{24}$

The practice of portraying composers holding rolls of paper became common in seventeenth-century Germany; the earliest example seems to be a woodcut of Johann Hermann Schein published in 1609 (Figure 5), only five years after Praetorius's portrait. It appeared in his first collection, Venus Kräntzlein, issued when he was twenty-three and studying law at Leipzig University. ${ }^{25} \mathrm{He}$ grasps a roll of paper with the Quinta Vox part

${ }^{24}$ For the portrait, see Rose, Musical Authorship from Schütz to Bach, 102-103.

${ }^{25}$ Reproduced, for instance, in Kinsky, History of Music, 167; Rose, Musical Authorship from Schütz to Bach, 105-107. 


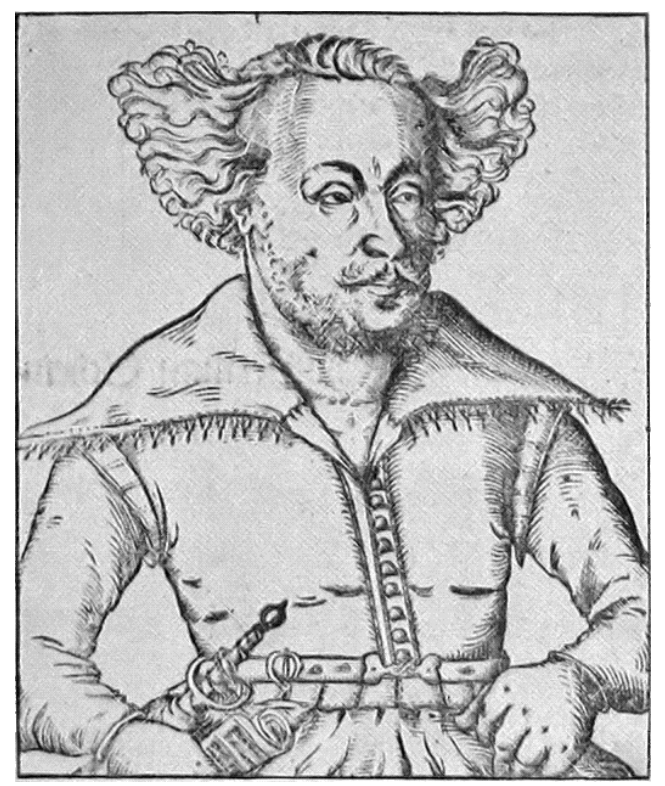

\section{Figure 5}

Portrait of Johann Hermann Schein, published in Venus Kräntzlein, Wittenberg, 1609. (Public domain.)

of the last piece in the collection, a quodlibet where that voice sings "Post Martinum, bonum vinum", suggesting that Schein, in the words of Stephen Rose, "fashioned himself for his portrait via the rituals of student masculinity rather than as an authoritative figure". Nevertheless, the roll of paper became the standard signifier that the sitter was a Kapellmeister as well as a composer, or least a potential leader of ensembles. There is a later portrait of Schein at Leipzig with a more sober hair style, dated 1620 when he was thirty-four; in it, he also holds a roll of paper. ${ }^{26}$ It is interesting, therefore, that in Schein's 1623 title page all three time-beaters just use their hands.

A selection of later portraits of German composers grasping rolls of paper must include Christoph Spetner's portrait of Heinrich Schütz, made around 1650 and subsequently engraved, ${ }^{27}$ although a portrait supposedly of Schütz painted by Rembrandt around 1633 turns out to be a red herring, since the Dutch painter and the Dresden-based composer apparently never crossed paths. ${ }^{28}$ It must be by another painter or portray someone else, and it has been suggested more convincingly that the sitter is the Dutch diplomat and amateur musician Constantijn Huygens. ${ }^{29}$ The Viennese court Kapellmeister Antonio Bertali was depicted with a roll of music paper in an engraved portrait dated October $1664 .{ }^{30} \mathrm{He}$ was

${ }^{26}$ In the Musikinstrumenten-Museum, Leipzig, reproduced, for instance, in Snyder and Johnston, "Johann Hermann Schein".

${ }^{27}$ In the Universitätsbibliothek, Leipzig, reproduced, for instance, in Rifkin et al., "Heinrich Schütz"; the engraving is reproduced, for instance, in Kinsky, History of Music, 166.

${ }^{28}$ In the National Gallery of Art, Washington DC; for the painting, see The Rembrandt Database (http://rembrandtdatabase.org/), accessed 13 May 2019.

${ }^{29}$ See Brook and Oja, "Rembrandt's Portrait of a Musician".

${ }^{30}$ A copy is reproduced, among other places, in the Wikipedia article on Bertali, accessed 13 May 2019. 


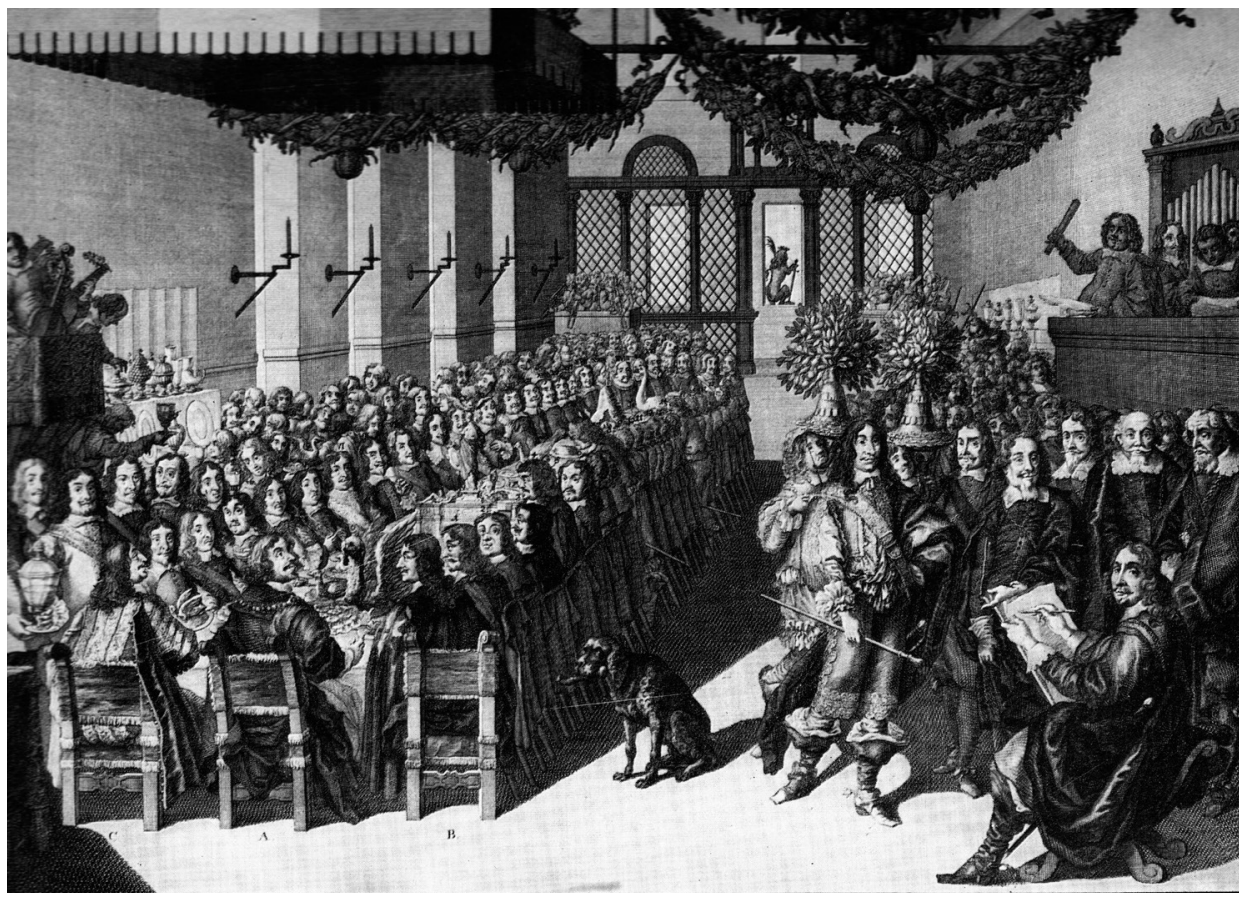

Figure 6

Engraving by Georg Daniel Heumann (1736) of Joachim von Sandart's painting Das Friedensmal, depicting the banquet given in Nürnberg on 25 September 1649 to celebrate the end of the Thirty Years War. (Public domain.)

a virtuoso violinist, but there is only more music and an inkpot on the table beside him where his instrument could have been placed, so he clearly felt that at the age of fifty-nine he had left violin playing behind for time-beating and composing. Bertali's Viennese colleague, the organist Alessandro Poglietti, is also depicted holding a roll of paper in an engraving made from a lost painting of 1680 by Jan Erasmus Quellinus. ${ }^{31}$ Again, it may be significant that he is not shown with a keyboard instrument; like Bertali, he clearly thought it more important to be portrayed as a composer and musical director than as a virtuoso instrumentalist.

Sigismund Theophil Staden (1607-1655), organist of St. Lorenz in Nürnberg, was depicted with a roll of paper in a posthumous engraved portrait, ${ }^{32}$ and was also featured in an early depiction of large-scale music controlled by a time-beater with a roll of paper. Joachim von Sandrart's painting Das Friedensmal, depicting the banquet given in Nürnberg on 25 September 1649 to celebrate the end of the Thirty Years War, shows

31 A copy at Göttweig Abbey in Lower Austria is reproduced in its Graphic Art Collection, accessed 13 May 2019.

${ }^{32}$ Reproduced, for instance, in Kinsky, History of Music, 173; Samuel, "Sigmund Theophil [Gottlieb] Staden". 
Staden directing four choirs of voices and instruments in the four corners of the banqueting hall. ${ }^{33}$ The painting was the subject of at least six engravings, some of which follow it in showing a subsidiary time-beater with each choir, although others, such as the one by Georg Daniel Heumann published in 1736, omit them (Figure 6). By then the practice of using more than time-beater had passed into history, as had the practice of depicting German composers with rolls of paper. Eighteenth-century composers tend just to have unfurled sheets of paper or music books in front of them, as in well-known portraits of Telemann and J.S. Bach. ${ }^{34}$

However, the fashion for rolls of paper was just starting in other countries, as exemplified by the collection of composer portraits at Bologna initiated by Padre Martini. ${ }^{35}$ More than forty of its portraits show the sitter holding a roll of paper; they range in date from a posthumous painting of Legrenzi to an engraving of Donizetti - the latter illustrating how late the modern baton and its technique came to Italy. The fashion caught on in England only in the eighteenth century, although there is a fascinating recently discovered painting apparently depicting the singer, lutenist and composer Nicholas Lanier, Master of the King's Music until the Civil War (Figure 7); it can be dated by the fashionable clothes, particularly the lace collar, to around 1644 or $1645 .{ }^{36}$ If it really does depict Lanier (the identification is based on comparisons with his other portraits and is tentative at present), ${ }^{37}$ then it was painted at the critical moment when he was on the point of leaving England for the Netherlands. With the country in chaos and King Charles I rapidly losing the Civil War, Lanier might well have thought he would never be coming back to England. I suspect his portrait was intended to advertise his wares to potential employers on the Continent. Note how the roll of paper is slightly unfurled, revealing the beginning of a piece of music in score (Figure 7a), an instance of a common topos indicating a dual role for the sitter as musical director and composer. The piece is apparently a two- or three-voice motet with continuo starting with the words "O Dulcis" - "O Dulcis Jesu" perhaps. Lanier was seemingly signalling that, as well as organizing and directing ensembles, he could provide the sort of petit motet that chapels in Brussels, Antwerp or Paris would have required.

Returning to the Praetorius title page (Figure 1), we can see that the time-beaters read from part-books. If the Kapellmeister is just beating time without singing, then he is likely to be reading from a continuo part. Praetorius, quoting Viadana, wrote that the "Capelmeister oder Chori Director" beats time with "the continuo part continually to

${ }^{33}$ In the Stadtmuseum, Nürnberg; engravings are reproduced, for instance, in Kinsky, History of Music, 174; Schwab, Konzert, 40-41. See also Zohn, "Telemann's Musique de Table and the Tafelmusik Tradition", 8-12.

${ }^{34}$ Reproduced, for instance, in Kinsky, History of Music, 253, 257; Zohn, "Georg Philipp Telemann"; Emery and Wolff, "Johann Sebastian Bach".

${ }^{35}$ Reproductions in the Portrait Gallery, Istituzione Bologna Musei, (http://www.museibologna. it/) accessed 13 May 2019.

${ }^{36}$ I am grateful to Tassilo Erhardt for information about the painting, and for allowing me to reproduce it.

${ }^{37}$ For other portraits of Lanier, see Thomson, "Iconography and Attribution"; Hebbert, "A New Portrait of Nicholas Lanier". 

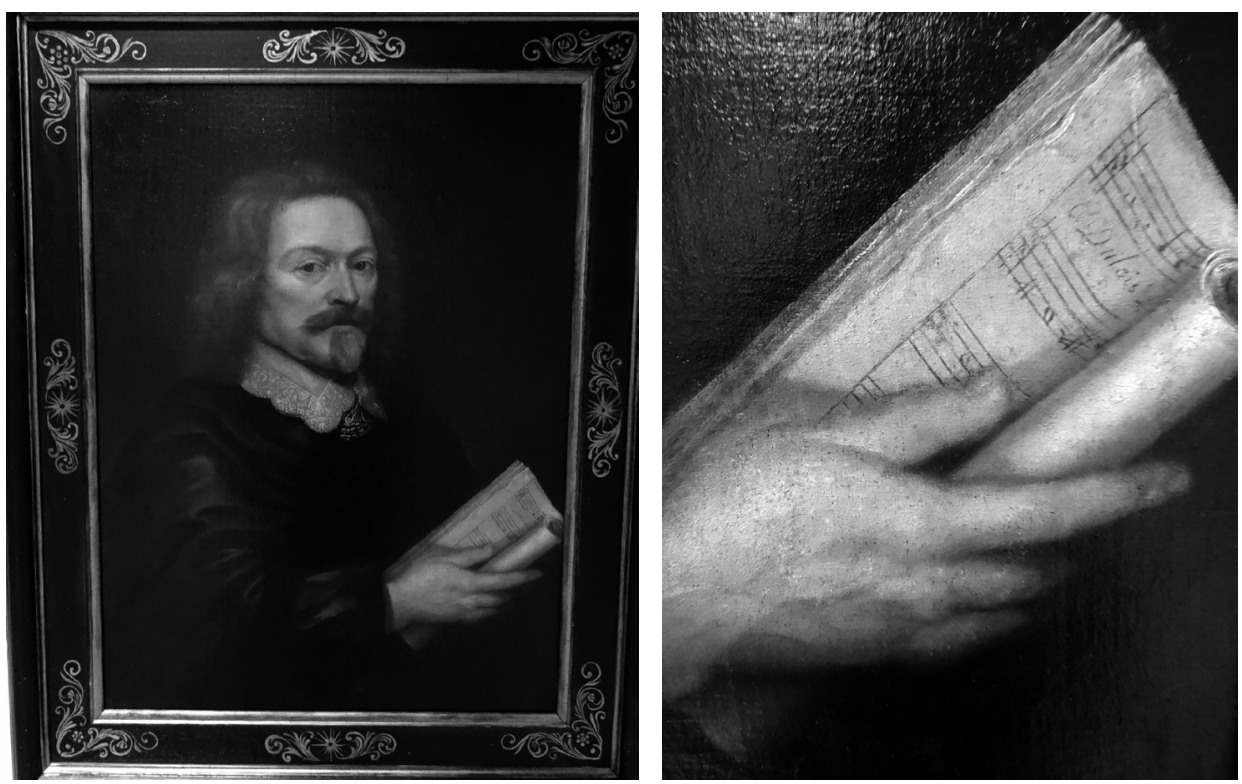

Figures 7 and $7 \mathbf{a}$

Anonymous portrait of a musician, probably Nicholas Lanier (c. 1645), and detail. (Reproduced by permission from Erhardt Fine Art.)

hand, or that which the organist has before him". ${ }^{38}$ Nicolaus Gengenbach pointed out in 1626 that basso seguente parts were "ein fein Compendium" for the director, allowing him to see where time-changes occur and where there are solos and tuttis. ${ }^{39}$ There are a number of parts of this sort in seventeenth-century sets of performing material, sometimes labelled "Guida", as mentioned by Praetorius in Syntagma musicum and found in parts for two Gabrieli pieces at Kassel;40 "Basso per la Battuta", as in Schmelzer's Missa Nuptialis in the monastery library at Kremsmünster; ${ }^{41}$ or "M.D.C." - maestro da capella - in the Kremsmünster set for Biber's Missa sancti Henrici, copied in $1701 .{ }^{42}$ In the set at Modena for J. C. Pez's motet Hodie Christus natus est there is an extra bass part, originally marked "Basso" and "Organo", but with "Organo" crossed out and "pour la mesure" inserted. ${ }^{43}$ Basso seguente parts would have given a time-beater all the information needed for effective direction, but would have been convenient to hold or place on a music desk, allowing him to use both hands in the tuttis.

${ }^{38}$ Butt, Music Education and the Art of Performance, 99-100; Praetorius, Syntagma musicum III, 116.

${ }^{39}$ Gengenbach, Musica nova, newe Singkunst, 147.

${ }^{40}$ Praetorius, Syntagma musicum III, 133; Charteris, Giovanni Gabrieli, 212-213, 268-269.

${ }^{41}$ Kremsmünster, Benediktinerstift, Musikarchiv (A-KR), C11/683.

${ }^{42}$ A-KR, C12/685; see Biber, Missa sancti Henrici, 103.

${ }^{43}$ Modena, Biblioteca Estense (I-MOe), mus.d.317, (http://bibliotecaestense.beniculturali.it/info/ img/mus/i-mo-beu-mus.d.317.pdf), accessed 13 May 2019. 
An alternative to a basso seguente part was full score, notated in organ tablature as well as staff notation. It is usually assumed that scores were copied principally to transmit or store music, but some of them also seem to have been used by organists in performance. A tell-tale sign that this is so is the stratigraphic format, with the music copied or printed right across the opening, so that the player has to move the eye from system to system only half the number of times required for a conventional score. Good examples are the staff notation score-books copied by Adam Gumpelzhaimer, cantor of St Anna in Augsburg, containing motets by Giovanni Gabrieli, Hans Leo Hassler and their contemporaries. ${ }^{44}$ Features suggesting that Gumpelzhaimer used them to direct from the organ include - apart from the stratigraphic format - added dynamics and accidentals, indications of instrumentation, aides-mémoire locating sets of parts, and texts added solely to the lowest sounding part, where they would be of most use to an organist. The player might have been Gumpelzhaimer himself, or (following Viadana) he might have acted as the time-beater, looking over the shoulder of an assistant at the organ.

In polychoral music organists could easily have played from basso seguente parts as well as scores, since it tends to proceed more in block chords than in counterpoint. However, in small-scale contrapuntal music the normal mode of accompanying was to double the lines more or less literally, which is why Schütz and his German composers preferred organists to use scores rather than continuo parts as late as the $1650 \mathrm{~s} .{ }^{45}$ Praetorius wrote that continuo parts were "not designed for the sake of apathetic or dilatory organists who dislike writing out their parts, but principally so that an organist can more easily prepare a score [Partitur] or tablature". ${ }^{46}$ Small and medium-sized groups could easily have kept time by listening to the organ without the help of a time-beater, as choirs certainly did in English cathedrals from the seventeenth to the twentieth centuries. ${ }^{47}$

The largest collection of seventeenth-century tablature scores was copied by the Swedish court Kapellmeister Gustav Düben and his associates from the 1660s; they are now in Uppsala University Library. ${ }^{48}$ They, too, are copied in stratigraphic format, sometimes without text and often with figures added above the bass line, particularly in solo passages where the harmonies are not obvious from the upper parts, which suggests that they were used by Düben while directing from the organ. For instance, Buxtehude's solo vocal concerto Fallax mundus ornat vultus BuxWV 28, for soprano, two violins and continuo, exists in Düben's tablature score as well as a set of staff-notation parts. ${ }^{49}$ The set includes two figured bass parts, so either the piece was performed with more than one continuo player or the tablature score was copied more for archival purposes than for

${ }^{44}$ Charteris, Little-Known Score-Books; and the items cited in idem, "Late Renaissance Music Manuscript", 3n6. For a parallel case, a group of tablature scores copied in eastern Slovakia in the early seventeenth century, see Kite-Powell, "Notating-Accompanying-Conducting".

${ }^{45}$ Johnston, "Polyphonic Keyboard Accompaniment".

${ }^{46}$ Praetorius, Syntagma musicum III, 133.

${ }^{47}$ A topic covered in detail in Holman, Before the Baton, chap. 1.

${ }^{48}$ Especially Uppsala University Library (S-Uu), Vmhs 77-81; digital images are at The Duben Collection Database (https://www2.musik.uu.se/duben/Duben.php). See also Schildt, "Gustav Düben at Work", especially 76-78, 134-138.

${ }^{49}$ S-Uu, Vmhs 083:069-073, fols. 8v-11 (tablature); 050:016 (parts). 
performance. Juliane Peetz's suggestion that Düben used his tablature scores in the modern manner for conducting performances "from the front" ${ }^{\prime 0}$ is the least likely in my opinion, particularly since many pieces, such as Fallax mundus, are for small forces that would not have needed a time-beater. I have yet to find convincing evidence that seventeenthcentury time-beaters ever read from scores placed on a rostrum in the modern fashion; that practice seems to have started only during the eighteenth century.

Finally, a few things need to be said about how seventeenth-century time-beating differed from modern conducting. I have already suggested that it consisted just of simple vertical hand movements; lateral movements, allowing subdivision of the beat, were mentioned by a few seventeenth-century theorists, ${ }^{51}$ but down-up remained the mainstream practice and was still being recommended in Britain and America in the early nineteenth century, long after modern-type baton conducting had been established in France and Germany. ${ }^{52}$ The seventeenth-century time-beater's job was just to maintain good ensemble, not to enforce his personal interpretation of the music, to shape the music in performance, to give the audience a pantomimic interpretation of what they were hearing or even to give cues for entries. This was not because he was ineffective or what he was doing was quaint or primitive, as is usually assumed today. It was to allow his singers and instrumentalists the maximum individual autonomy consistent with good ensemble, so that the members of even large ensembles could take individual responsibility for a collective interpretation within agreed stylistic norms. For modern parallels we should look beyond Classical music (and unfortunately even beyond most supposedly historically informed performances of early music) to big band jazz. Duke Ellington, for instance, was just primus inter pares of a prodigiously talented ensemble that certainly did not need conducting; photographs of his orchestra performing - as opposed to posed publicity shots - sometimes show him just playing the piano placed unobtrusively at the side of his orchestra. In my opinion we should think very hard about using modern baton conducting in music written long before the tyranny of the baton was established.

${ }^{50}$ Peetz, "The Large Tablature Books in the Düben Collection", 69.

${ }^{51}$ Discussed in Houle, Meter in Music, 5-9; Galkin, History of Orchestral Conducting, 261-263.

${ }^{52}$ For instance, in the article "Beating Time", Busby, Complete Dictionary of Music. 


\section{Bibliography}

Arnold, Denis. Giovanni Gabrieli and the Music of the Venetian High Renaissance. Oxford: Oxford University Press, 1979.

Biber, Heinrich Ignaz Franz. Missa sancti Henrici. Edited by Armin Kircher. Stuttgart: Carus, 2004.

Bowles, Edmund A. Musical Ensembles in Festival Books, 1500-1800: An Iconographical \& Documentary Survey. Ann Arbor MI: UMI Research Press, 1989.

Brentel, Friedrich, and Matthäus Merian. Decem insignae tabulae, complexae icones justorum ac honorum supremorum, corpori serenissimi principis Caroli III [...] Lotharingae ducis [...] in eius exequiispersolutorum. Nancy: Blasium Andream, 1611.

Brook, Barry S., and Carol Oja. "Rembrandt's Portrait of a Musician". College Music Symposium 18 (1 October 1978): 132-135. Accessed 13 May 2019. https://symposium. music.org.

Bryant, David. "The Cori Spezzati of St. Mark's: Myth and Reality”. Early Music History 1 (1981): 165-186. https://doi.org/10.1017/S0261127900000280.

Busby, Thomas. A Complete Dictionary of Music. London: R. Phillips, c. 1801. Accessed 13 May 2019. https://books.google.co.uk.

Butt, John. Music Education and the Art of Performance in the German Baroque. Cambridge: Cambridge University Press, 1994. https://doi.org/10.1017/CBO9780511597312.

Charteris, Richard. Adam Gumpelzhaimer's Little-Known Score-Books in Berlin and Kraków. Neuhausen: Hänssler, 1996.

- Giovanni Gabrieli (c. 1555-1612): A Thematic Catalogue of his Music with a Guide to the Source Materials and Translations of his Vocal Texts. Stuyvesant NY: Pendragon Press, 1996.

_. "A Late Renaissance Music Manuscript Unmasked". The Electronic British Library Journal (2006): 1-24. Accessed 13 May 2019. http://www.bl.uk/eblj/2006articles/ article3.html.

_. "Newly Discovered Works by Giovanni Gabrieli". Music \& Letters 68 (1987): 343-363. https://doi.org/10.1093/ml/68.4.343.

Coelho, Victor, and Keith Polk. Instrumentalists and Renaissance Culture, 1420-1600: Players of Function and Fantasy. Cambridge: Cambridge University Press, 2016. https://doi.org/10.1017/CBO9781316536186.

Coryat, Thomas. Coryat's Crudities. London: W.S., 1611.

Emery, Walter, and Christoph Wolff. “Johann Sebastian Bach”. In Grove Music Online. Accessed 13 May 2019. https://doi.org/10.1093/gmo/9781561592630.article.6002278195.

Galkin, Elliott W. A History of Orchestral Conducting in Theory and Practice. New York: Pendragon Press, 1988.

Gengenbach, Nikolaus. Musica nova, newe Singekunst. Leipzig: Zentralantiquariat der DDR, 1980.

Glixon, Jonathan. Honoring God and the City: Music at the Venetian Confraternities, 1260-1807. Oxford: Oxford University Press, 2003. https://doi.org/10.1093/acprof: oso/9780195134896.001.0001. 
Hebbert, Benjamin M. “A New Portrait of Nicholas Lanier”. Early Music 38, no. 4 (2010): 509-522. https://doi.org/10.1093/em/caq080.

Holman, Peter. Before the Baton: Musical Direction and Conducting in Stuart and Georgian Britain. Woodbridge: Boydell \& Brewer, in press.

Houle, George. Meter in Music, 1600-1800: Performance, Perception and Notation. Bloomington: Indiana University Press, 1987. Reprinted 2000.

Johnston, Gregory S. "Polyphonic Keyboard Accompaniment in the Early Baroque: An Alternative to Basso Continuo". Early Music 26, no.1 (1998): 51-64. https://doi. org/10.1093/earlyj/XXVI.1.51.

Kinsky, Georg. A History of Music in Pictures. London: J.M. Dent and Sons, 1930. Reprinted 1937.

Kirwan, A. Lindsey, and Lothar Hoffmann-Erbrecht. "Johann Martin Rubert [Rubbert]". In Grove Music Online. Accessed 12 May 2019. https://doi.org/10.1093/ gmo/9781561592630.article.24045.

Kite-Powell, Jeffery T. "Notating-Accompanying-Conducting: Intabulation Usage in the Levoča Manuscripts”. In Proceedings of the Göteborg International Organ Academy 1994, edited by Hans Davidsson and Sverker Jullander, 99-129. Gothenburg: Gothenburg University, 1994.

MacClintock, Carol. Readings in the History of Music in Performance. Bloomington: Indiana University Press, 1979.

Maugars, André. Response faite à un curieux, sur le sentiment de la musique d'Italie. Escrite à Rome le premier Octobre 1639. [Paris: c. 1640]. Reprint, Geneva: Minkoff, 1993.

Mersenne, Marin. Harmonie universelle. Vol. 2, bk. 5. Paris: Guillaume Baudry, 1636-1637. Peetz, Julia. "The Large Tablature Books in the Düben Collection". In The Dissemination of Music in Seventeenth-Century Europe: Celebrating the Düben Collection, edited by Erik Kjellberg, 49-72. Bern: Peter Lang Verlag, 2010. https://doi. org/10.3726/978-3-0351-0068-6/5.

Praetorius, Michael. Syntagma musicum III. Translated and edited by Jeffery Kite-Powell. New York: Oxford University Press, 2004.

Rifkin, Joshua, Eva Linfield, Derek McCulloch and Stephen Baron. "Heinrich Schütz". In Grove Music Online. Accessed 13 May 2019. https://doi.org/10.1093/gmo/9781561592630. article.45997.

Rose, Stephen. Musical Authorship from Schütz to Bach. Cambridge: Cambridge University Press, 2019. https://doi.org/10.1017/9781108363280.

Samuel, Harold E. “Sigmund Theophil [Gottlieb] Staden”. In Grove Music Online. Accessed 13 May 2019. https://doi.org/10.1093/gmo/9781561592630.article.26506.

Schildt, Maria. "Gustav Düben at Work: Musical Repertory and Practice of Swedish Court Musicians, 1663-1690”. PhD diss., University of Uppsala, 2014.

Schwab, Heinrich W. Konzert: Öffentliche Musikdarbietung vom 17. bis 19. Jahrhundert. Musikgeschichte in Bildern, Vol. 4, Musik der Neuzeit, Lfg. 2. Leipzig: Deutscher Verlag für Musik, 1971.

Selfridge-Field, Eleanor. "Gabrieli and the Organ”. The Organ Yearbook 8 (1977): 2-19. Snyder, Kerala J., and Gregory S. Johnston. "Johann Hermann Schein”. In Grove Music 
Online. Accessed 13 May 2019. https://doi.org/10.1093/gmo/9781561592630. article. 24787.

Spencer, Robert. "Chitarrone, Theorbo and Archlute". Early Music 4, no. 4 (1976): 407-423. https://doi.org/10.1093/earlyj/4.4.407.

Spitzer, John, and Neal Zaslaw. The Birth of the Orchestra: History of an Institution, 1650-1815. Oxford: Oxford University Press, 2004.

Thomson, Duncan. "Iconography and Attribution". In Nicholas Lanier 1588-1666: A Portrait Revealed, edited by Duncan Thomson, 28-37. London: Weiss Gallery, 2010. Accessed 13 May 2019. https://issuu.com/theweissgallery/docs/2010-weiss-gallery-lanier.

Viadana, Lodovico Grossi da. Salmi a quattro cori. Edited by Gerhard Wielakker. Recent Researches in the Music of the Baroque Era 86. Madison WI: A-R Editions, 1998.

Walther, Johann Gottfried. Musicalisches Lexicon. Leipzig: Wolffgang Deer, 1732. https:// imslp.org/wiki/Musicalisches_Lexicon_(Walther,_Johann_Gottfried).

Weigel, Johann Christoph. Musicalisches Theatrum. Nürnberg: author, c. 1722.

Zohn, Steven D. "Georg Philipp Telemann”. In Grove Music Online. Accessed 13 May 2019. https://doi.org/10.1093/gmo/9781561592630.article.27635.

-. "Telemann's Musique de Table and the Tafelmusik Tradition". Oxford Handbooks Online (April 2016). Accessed 13 May 2019. https://dx.doi.org/10.1093/ oxfordhb/9780199935321.013.120. 


\section{NASLOVNICA MICHAELA PRAETORIUSA}

\section{Povzetek}

Okvir dekorativne grafike, ki jo je Michael Praetorius uporabil za nekaj naslovnic svojih tiskanih del - od prvega dela zbirke Musae Sioniae (1605) do dodatka svojega traktata Syntagma musicum z naslovom Theatrum instrumentorum (1620) -, predstavlja izhodišče za razpravljanje o načinu izvajanja glasbe okoli leta 1600, še posebno izvajanja italijanske in nemške glasbe za obsežne pevske sestave. Grafika prikazuje tri zborovske skupine: prvi zbor sestavljajo pevec in trije godalci z organistom, drugi zbor ima pevce s tremi cinkisti in glasbenikom za regalom. Ta zbora se nahajata na levem in desnem balkonu. Tretji zbor iz štirih pevcev, dveh pozavnistov, glasbenika z velikim trobilom (verjetno sordunom) in glavnimi orglami pa je postavljen v sredino spodaj.

Praetoriusova ponazoritev je sorodna skupini, upodobljeni na naslovnici zbirke Fontana d'Israel ali Israelis Brünnlein (1623) Johanna Hermana Scheina. Grafika prikazuje italijanski način izvajanja, kakršen izhaja iz poznih motetov Giovannija Gabrielija in ki ga je opisal tudi Lodovico da Viadana v uvodu k svojim Psalmom za štiri zbore (to besedilo je Praetorius povzel v svoji Syntagmi musicum III), v okviru opisa glasbenih izvedb v Rimu in Benetkah. Skupina na Scheinovi naslovnici je še posebno blizu Gabrielijevi praksi. Ta je visoke in nizke glasove zasedel s pevcem ter tremi cinkisti oziroma pozavnisti. Pri Praetoriusu tretji zbor zasedajo štirje pevci, medtem ko se zdi, da na Scheinovi naslovnici nastopajo vsi preostali pevci in inštrumentalisti, ki so bili na voljo.

$\mathrm{Na}$ obeh naslovnicah skupine glasbenikov vodi kapelnik z dvignjeno roko, ki stoji tik ob organistu in pevcem prvega in drugega zbora nakazuje glasbeno dobo. Viadana priporoča, da maestro di capella hkrati gleda tudi organistov part za izvajanje continua in da »se na tutti mestih ozre k vsem zborom ter dvigne obe roki«. Iz tega je tudi razvidno, zakaj na nekaterih poznejših upodobitvah vodje dobo nakazujejo z zvitkom papirja v vsaki roki. Če je na upodobitvi viden glasbeni zapis, gre navadno za basso seguente part in ne partituro; nekateri takšni basovski parti iz ohranjenega izvirnega izvajalskega gradiva so včasih poimenovani tudi »Guida« (vodnik), »Basso per la Battuta« (bas za dobo) ali »M.D.C.« (maestro da capella, kapelnik). V partiturah 17. stoletja je pogosto uporabljena stratigrafska oblika zapisa, kar kaže na to, da so bili taki zapisi namenjeni organistom; izvajalec se je na ta način z očmi lahko samo sprehodil iz sistema v sistem dakrat manj kakor pri polni partituri. Pred 18. stoletjem vodje, ki so stali na posebnem odru, niso uporabljali partitur.

Upodobitve kažejo, da so vodje še vse do časa po letu 1600 za nakazovanje uporabljali samo roke, kot dokazujeta naslovnici Praetoriusovih knjig in Scheinove zbirke. Vendar pa so se kmalu po tem času predvsem v nemškem prostoru uveljavili portreti skladateljev z zvitki notnega papirja v rokah. Eden prvih je Scheinov portret, natisnjen leta 1609. Upodobitve vodij, ki so z zvitki nakazovali glasbene dobe, so bile od okoli leta 1650 že povsem običajne. Ena teh je slika, ki prikazuje Sigismunda Theophila Stadena, kako vodi skupino štirih zborov v Nürnbergu leta 1649. V 17. stoletju so dobe navadno nakazovali z gibom roke od spodaj navzgor in puščali izvajalcem kar največ svobode za osebno 
interpretacijo v skladu z dobro skupinsko igro. Nikakor pa niso počeli vsega, kar delajo današnji dirigenti, da bi poudarili svojo osebno interpretacijo izvajanih glasbenih del. 